\title{
Sero-Prevalence Of Brucellosis In Goats And Community Awareness In Liban District Of Guji Zone, Oromia Regional State, Southern Ethiopia
}

\author{
Wubishet $\mathrm{Z}^{1}$, Golo $\mathrm{D}^{1}$, Chala $\mathrm{F}^{2}$, Shubisa $\mathrm{A}^{1}$, Huqa L Godana $\mathrm{H}^{3}$ and Ararsa $\mathrm{D}^{4}$ \\ ${ }^{1}$ Oromia Pastoral Area Development Commission Yabello Regional Veterinary Laboratory, Ethiopia \\ ${ }^{2}$ Alage Federal Agricultural Technical Vocational Education and Training College, Ethiopia \\ ${ }^{3}$ Oromia Pastoralist Area Development Commission, Dida Tuyura Borena Breed genetic improvement and breeding center, Ethiopia \\ ${ }^{4}$ Haramaya University School of Veterinary Medicine, Africa, Ethiopia
}

Submission: August 18, 2017; Published: August 30, 2017

*Corresponding author: Wubishet Zewdie, Oromia Pastoral Area Development Commission Yabello Regional Veterinary Laboratory, Ethiopia, Email: wubevet1921@gmail.com

\begin{abstract}
A cross-sectional study was conducted to determine sero prevalence of brucellosis, community awareness about zoonotic importance of the disease and its transmission to goat owners in Liban district of Guji zone Oromia regional state, southern Ethiopia. Study was conducted on 413 goats that are managed under pastoral production system. Sera samples were serially tested using Rose Bengal Plate Test (RBPT). Positive sera samples were retested by complement fixation test (CFT). Questionnaire survey was administered to 153 goat owners to assess community awareness. Collected data was analyzed using SPSS version 15 software. The study showed that goat brucellosis is a moderately distributed with overall sero-prevalence of $6.2 \%$ in Liban district. All $153(100 \%)$ respondents in the area recognized abortion but 136 (88.9\%) of the respondents have no awareness about zoonotic importance of brucellosis. The current study has determined women and children to be the risky group with higher probability of being infected with brucellosis from goats relative to men as result of close contact they have with goats during parturition, handling of cases like aborted foetus and retained placenta bare handed, milking and caring after goats. Therefore, awareness creation to the community and elimination of positive reactors are recommended to control brucellosis in the area.
\end{abstract}

Keywords: Brucellosis; Community awareness; Goats; Guji; Risky groups; Sero-prevalence

\section{Introduction}

Brucellosis is a contagious disease caused by bacteria of genus Brucella. In livestock, it is mainly a reproductive disease of the sexually mature animals with predilection site of placenta, fetal fluids and testes of male animals Wadood 2009. It has been recognized as a global problem of wild and domestic animals, especially cattle, sheep and goats Rijpens [1]. The disease is primarily an occupational risk in exposed professions, i.e. veterinarians, farmers, laboratory technicians, abattoir workers, and others who work with animals and their products. The primary source is the animal and infection is contracted either by direct or indirect contact through the skin or mucous membranes or ingestion of contaminated products, especially fresh dairy products. Pastoralists, especially women have direct contact while milking and helping ewes when deliver even with cases like aborted fetus of ewes and retained placenta which could increase the chance of infection with brucellosis Muhammed [2].

Brucellosis is prevalent in all major livestock production systems in sub-Saharan Africa, yet its presence often remains unrecognized through lack of awareness by both veterinarians and health care staff and absence of accessible laboratory diagnostic facilities. As a consequence brucellosis remains a largely neglected disease with little attention to control and prevention except in South Africa where a successful control policy has been instigated McDermott, Arimi [3] Preliminary data suggests that the incidence of brucellosis is highest in pastoral production system where large number of animal mix and lowest for confined farms Muriuki [4], Habtamu [5].

Goat brucellosis has significant economic and zoonotic implication for the pastoral communities in Ethiopia in 
consequence of their traditional life styles, feeding habits and disease patterns. Hence, knowledge of brucellosis occurrence in pastoral production system has considerable importance in reducing the economic and public health impacts of the disease Rahman and Dabasa [6] In Ethiopia, pastoral area covers sixty percent of the total land mass and holding inhabitants more than 10 million of people in seven regional states and Oromia pastoral area shares the largest percentage of pastoralism in the country PFE, 2004.

Serological studies of brucellosis have been carried out in farm and pastoral areas of the country. However, only few studies have been conducted on small ruminants brucellosis. Reported prevalence include $15 \%$ in sheep and $16.5 \%$ in goats in Afar Teshale [7] 3.2\% in sheep and 5.8\% in goats in Afar Ashenafi [8] and $3.2 \%$ in goats and $1.6 \%$ in sheep Mengistu in Konso; 1.37\% Mindaye [2] 9.6\% Yohannes [9] The presence of Fraser [10] brucellosis in livestock varies between different regions of the country Hoover and Friedlander [11] Maloney, Furthermore, only few serological studies demonstrated the occurrence of the disease among Borana and Hamer pastoralists PFE 2004.

Pastoralists of Borana area have cultural indigenous range and water ponds management knowledge governing pasture and water ponds and thus settlement is based on some predetermined scenario which allow some group of the community or clan to use these resources Oba [11]. This kind of settlement and livestock mixing, however, can favor disease transmission easily. Study conducted by Dabasa [6] shows that there is history of the disease in the area where sheep and goats are affected by the disease at the prevalence rate of 1.17 and $1.88 \%$, respectively. This indicates that there was no study conducted on separate species of these animals. In particular, there is little information on goat brucellosis across various livestock production systems of southern part of the country, which gave impetus to the initiation of this study. Therefore, this study was designed to undergo serological survey of brucellosis in goats and community awareness about the disease in Liban district of Guji zone.

\section{Materials and Methods}

\section{Study Area}

The study was conducted in Liban districts of Guji zone pastoral area, Oromia regional state, southern Ethiopia. Guji zone comprises five pastoral districts namely Liban, Gorodola, Wadara, Girja and Sababoru. Liban district was selected based on presence of high goat population relative to other districts in Borena zone. The major animal species kept in the area include cattle, goat, sheep, camels, poultry, donkeys, mule and horses. Next to cattle, goats are the most important animal species kept in the area for milk production and income generation for small holders. The predominant goats are managed under pastoralism production system (Figure 1).

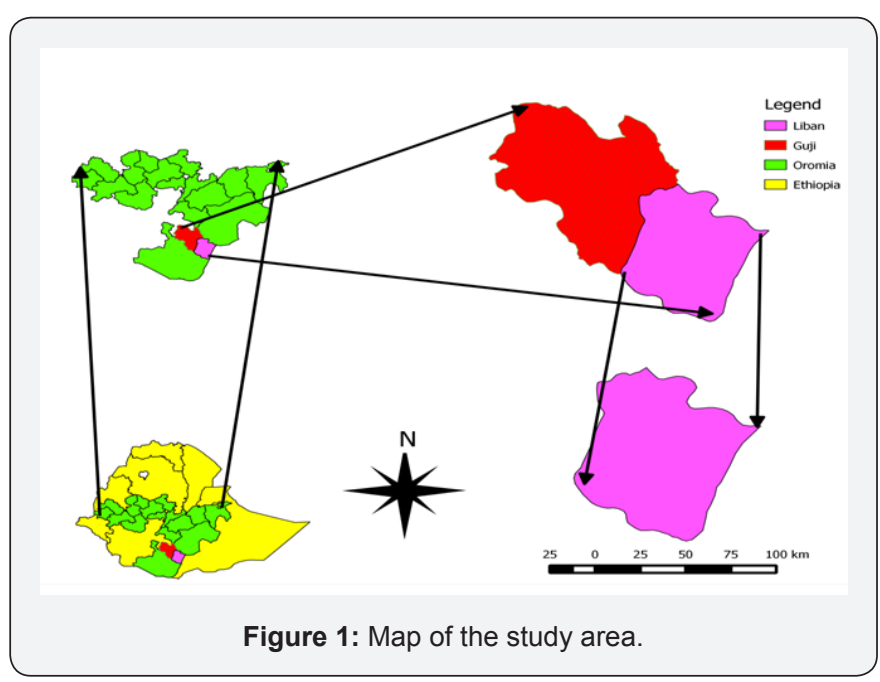

\section{Study Design and population}

A cross-sectional study was conducted on goats kept under pastoral system in Liben district. A total of 413 goats (378 females and 35 males) were tested using RBPT and CFT. All goats that were more than two years old were included in the study. Variables such as sex, age, abortion history, retained placenta and parity number were taken as potential risk factors. Information on each goat was recorded properly while collecting specimen from the goats. Visit to settlements and collection of sample was made early in the morning before the pastoralists start moving in search of pasture. Information related to management system of goats was recorded and responsible household member who care after the goats was also interviewed using semi structured questionnaires.

\section{Sample size and sampling}

Selection of animals was based on a stratified sampling method. Five (PAs) namely, Hadesakorat, Malkaguba, Siminto, Bulbul and Karsamale were selected based on their goat population. The five PAs were considered as strata, a total of 75 households were visited where fifteen (15) households were visited from each PAs. Villages and households were selected purposively based on the inclusion criteria (accessibility, willingness of the households to participate in research and security). Taking estimated prevalence of 3\% brucellosis in individual animal reported previously by Sintayehu [12] at the area; and taking a confidence interval of $95 \%$ and $5 \%$ absolute precision, sample size was determined using single proportion formula set by Thrusfield, 2005:

$$
\begin{aligned}
& \mathrm{n}=1.96^{2} \times \mathrm{P}_{\text {exp }}\left(1-\mathrm{P}_{\text {exp }}\right) \\
& \mathrm{d}^{2} \\
& \text { Where: }-\mathrm{n}=\text { the required sample size, } \\
& \quad-\mathrm{P}_{\exp }=\text { expected prevalence } \\
& \quad-\mathrm{d}=\text { desired absolute precision }
\end{aligned}
$$


Therefore, the minimum sample size required was 45 goats. However, to increase the representativeness of the study sample and reduce the design effect, sample size was increased by 9 fold and the total number of goats included was 413. Study animal-related information on each tested goat (such as sex, age, abortion history, retained fetal membrane) was collected and recorded at the time of test.

\section{Laboratory Techniques}

\section{Rose Bengal plate test (RBPT)}

All sera sample were initially screened by using Modified Rose Bengal Plate Test (mRBPT) antigen at Yabelo Regional Veterinary Laboratory. Sera and antigen were left at room temperature for half an hour before conducting the test. $75 \mu \mathrm{l}$ antigen and $25 \mu \mathrm{l}$ test serum were taken using micropipette and mixed thoroughly on the RBPT plate of the test box using a tooth pick and the box was hand rocked for $4 \mathrm{~min}$. Samples that showed signs of agglutination were recorded as positive while those with no sign of agglutination were recorded negative.

\section{Complement Fixation Test (CFT)}

The entire sera tested by RBPT and found to be positive for the test were subjected to CFT for confirmation. The test was conducted at National Animal Health Diagnostic and Investigation Centre (NAHDIC).

\section{Data collection and analysis}

All information related to study animal such as age, sex, abortion history and history of retained fetal membrane was recorded in Microsoft excel spread sheet. Recorded information and test result analyzed using SPSS version 15 statistical data analyzing software. Chi-square and P value report was analyzed to compare significance difference of suggestive risk factors.

\section{Result}

\section{Rose Bengal plate test (RBPT)}

Table 1: Sero-prevalence of goats Brucellosis in relation to different risk factors.

\begin{tabular}{|c|c|c|c|c|c|}
\hline Factors & Number of tested & Number of Positive (\%) & & Chi-square & P-value \\
\hline & & RBPT & CFT & & \\
\hline \multicolumn{6}{|l|}{ Sex } \\
\hline Male & 35 & $7(20.0)$ & $7(20.0 \%)$ & \multirow{2}{*}{12.17} & \multirow{2}{*}{0.000} \\
\hline Female & 378 & $20(5.3)$ & $19(5 \%)$ & & \\
\hline \multicolumn{6}{|l|}{ Age } \\
\hline Adult & 399 & $24(21.4)$ & $24(6.0 \%)$ & \multirow{2}{*}{1.5} & \multirow{2}{*}{0.210} \\
\hline Young & 14 & $3(6)$ & $2(14.3 \%)$ & & \\
\hline \multicolumn{6}{|c|}{ Retained FM } \\
\hline Yes & 11 & $2(18.2)$ & $2(18.2)$ & \multirow{2}{*}{4.1} & \multirow{2}{*}{0.43} \\
\hline No & 366 & $14(4.6)$ & $14(4.6)$ & & \\
\hline \multicolumn{6}{|c|}{ Abortion History } \\
\hline Yes & 43 & $7(16.3)$ & $7(16.3)$ & \multirow{2}{*}{12.8} & \multirow{2}{*}{0.000} \\
\hline No & 334 & $12(3.6)$ & $12(3.6)$ & & \\
\hline
\end{tabular}

Out of 413 goat sera screened with RBPT 27 (6.5\%), samples were found to be positive for Brucella antibodies. Of these RBPT positive sera, 26 were also found to be positive by CFT giving an overall confirmed brucellosis sero-prevalence of $6.3 \%$ in the study area (Table 1) Out of 153 goats owners 136 (88.9\%) said they had no awareness about zoonotic importance of brucellosis (Table 2), although almost all of them recognized the existence of abortion locally known, in local language (Afaan Oromo), as"Sallesu" mean abortion. Almost all pastoralists of Liban district assist does during parturition and in removing retained fetal membranes bare handed (Table 2). Drinking of goat milk is common in poor household regularly and it is also consumed in relatively rich family when there is no sufficient milk that they obtain from cows during dry season. However, most of the pastoral community consumes goat milk by boiling the milk with tea known as shayi ananan (shayi adessa) in local language to mean milk with tea (Table 2). Prevalence of Brucellosis is high in Hadesakorat relative in order by Siminto and Malkaguba but has no statistically significant variation between PAs (Table 3). 
Table 2: Owners' awareness, way of handling cases and way of consuming goat products.

\begin{tabular}{|c|c|c|}
\hline Factors & Number of respondents & Percentage (\%) \\
\hline Have awareness on brucellosis? & 17 & 11.1 \\
\hline No & 136 & 88.9 \\
\hline Way of handling aborted fetus and retained placenta & & 2 \\
\hline With bare hand & 3 & \\
\hline Glove or other protective & 30 \\
\hline Way of consuming goat product in the districts & 0 & 0 \\
\hline Boiled milk alone & 148 & 96.7 \\
\hline Boiled milk with tea & 5 & 3.3 \\
\hline Drink raw milk of goats & & \\
\hline Goat owner/attendant & 151 & 1.3 \\
\hline Children and Women & 2 & \\
\hline Men & & \\
\hline
\end{tabular}

Table 3: Prevalence of goat brucellosis relative to pastoralist associations (PAs).

\begin{tabular}{|c|c|c|c|c|}
\hline PAs & Number of tested & Number of Positives (Test Result) & CFT & Percentage by CFT (\%) \\
\hline Hadesakorat & & RBPT & 8 & 10.0 \\
\hline Malkaguba & 80 & 8 & 5 & 6.3 \\
\hline Siminto & 80 & 5 & 6 & 7.2 \\
\hline Bulbul & 83 & 7 & 4 & 4.1 \\
\hline karsamale & 72 & 3 & 3 & 4.2 \\
\hline Total & 413 & 27 & 27 & 6.3 \\
\hline
\end{tabular}

\section{Discussion}

Brucellosis is bacterial disease of animals with zoonotic and economic implication worldwide Corbel [13]. The overall sero-prevalence of goat's brucellosis in the current study area, based on RBPT was found to be $6.5 \%$ whereas on the basis of CFT, determined to be $6.2 \%$.The Seroprevalence of brucellosis showed that it is moderate relative to previous reports on brucellosis. This is fairly in agreement with the report of Yohaness [9] who reported $11.10 \%$ prevalence in goats using RBPT in Yabello district. However, the current finding result is lower than that of Al-Majali [14] where 27.7\% (305 of 1100) of goats were seropositive by RBPT and CFT. This result is slightly higher than report of Sintayehu [12] which was 3\% in Borena area of souther Ethiopia. But the present study is higher than, finding of Bekele [15] at Jijjiga who detected brucellosis 2.3\% (7 of 309) in goats using RBPT and 1.9\% (6 of 309) using CFT and Tekelye, Kasali [16] who recorded $1.3 \%$ in goats in central highlands of Ethiopia. This difference in sero-prevalence of brucellosis within the same ecosystem could be described as strong clan-based segregation of animals and range lands in the pastoral area Teshale, Bekele [16] Differences in geographical location and livestock management in the central high lands or low lands of the country could be due to mixed farming in the high lands, in which fewer animals are raised separately Ferede [17] However, the higher prevalence rate detected in pastoral area could be due to variations in the management practices in pastoral area, free movement of animals or frequent introduction of new animals without prior serological testing and keeping of animals with high incidence of abortions. This is in agreement with previous reports of Hamidullah [18], Negash [19].

In present study area, goat owners use common grazing range lands and watering points which created relatively higher prevalence rate of brucellosis as reported by different researchers on brucellosis Teshale [7] Negash [19] In the present study, a higher sero-prevalence recorded in males $(20.0 \%)$ than in females $(5.3 \%)$ with significance difference 
occurrence of brucellosis (Table 1); this result is contradictory to report of Negash [19] that serological prevalence was lower in males (8.99\%) as compared to females (9.22\%). This could be due the method used to collect sera sample and sex composition difference. In the present study, $88.9 \%$ of the pastoral community in the study area has no awareness on zoonotic importance of brucellosis. This is in agreement with study conducted in Jima zone by Bashahun [20-24] where they found that $97 \%$ of the respondents said they have no awareness on zoonotic importance of Brucellosis. Women and children are risky group among family members mainly exposed to the disease. Furthermore, 150 (98\%) of the owners were found to have habit of handling cases like abortion and retained placenta with bare hand which is in agreement with report of Bekele [14], Negash [19] Handling cases could be main way of transmission of disease from human to animals and increase chance of the risky groups to be infected by brucellosis [25-30].

\section{Conclusion}

Brucellosis is transmissible from animals to humans through consumption of contaminated milk, raw milk products, meat or direct contact with infected animals. Women and children's close contact with goats while milking and keeping flock, unsafe handling of placenta, aborted fetus and assisting births bare handed were common practices among analyzed population. These practices may predispose children and women to acquire brucellosis from goats which are reservoirs of the most pathogenic Brucella species, B.melitesis for human and animals [31]. Therefore, collaborative activity between veterinarians, physicians and other governmental and nongovernmental organizations is needed to take preventive and control action through educating communities and creating awareness on zoonotic importance of brucellosis.

\section{References}

1. Rijpens Nancy p, Jannes G, Van Asbroeck M, Rossau R, Herman LM (1996) Direct detection of Brucella spp.in raw milk by PCR and reverse hybridization with 16S23S rRNA spacer probes. Appl Enviro Microbiol 62 (5): $1683-1688$.

2. Mohammed M, Mindaye S, Hailemariam Z, Tamerat N, Muktar Y (2017) Sero-Prevalence of Small Ruminant Brucellosis in Three Selected Districts of Somali Region, Eastern Ethiopia. Journal of Veterinary Science \& Animal Husbandry 5(1): 2348-9790.

3. Kadohira M, McDermott JJ, Shoukri MM, Kyule MN (1997) Variations in the prevalence of antibody to brucella infection in cattle by farm, area and district in Kenya. Epidemiol Infect 118(1): 35-41.

4. Muriuki SM, McDermott JJ, Arimi SM, Mugambi JT, Wamola IA (1997) Criteria for better detection of brucellosis in the Narok District of Kenya. East Afr Med J 74(5): 317-320.

5. Habtamu TT, Richard B, Dana H, Kassaw AT (2015) Camel Brucellosis: Its Public Health and Economic Impact in Pastoralists, Mehoni District, Southeastern Tigray, Ethiopia. J Micro Res 5(5): 149-156.

6. Dabasa G, Tefera M, Addis M (2013) Small Ruminant Brucellosis: Serological Survey in Yabello District, Ethiopia. Asian J Ani Sci.
7. Teshale S, Muhie Y, Dagne A, Kidanemariam A (2006) Seroprevalence of small ruminant brucellosis in selected districts of Afar and Somali pastoral areas of Eastern Ethiopia: the impact of husbandry practice. Rev. Méd Vét 157(11): 557-563.

8. Ashenafi F, Teshale S, Ejeta G, Fikru R, Laikemariam Y (2007) Distribution of brucellosis among small ruminants in the pastoral region of Afar, eastern Ethiopia. Revue scientific ettechnique 26(3): 731-739.

9. Yohannes G (2012) Epidemiological investigation of brucellosis in ruminant and human in Yabello district of Borena pastoral area, Oromia national regional state, Africa.

10. Hoover DL, Friedlander AM (1997) Textbook of military medicine: medical aspects of chemical and biological warfare. Washington DC, US Department of the Army: Surgeon General \& Borden Institute 2: 513521.

11. Oba G (1998) Assessment of indigenous range management knowledge of the Borana pastoralists of Southern Ethiopia. Borana Low Land Pastoral Development Program/GTZ consultancy paper. Ethiopia.

12. Sintayehu G, Melesse B, Abayneh AD, Sintayehu, Melaku S, et al. (2015) Epidemiological survey of brucellosis in sheep and goats in selected pastoral and agro-pastoral lowlands of Ethiopia. Rev Sci Tech Off mnt Epiz 34(3): 881-893.

13. Corbel MJ (2006) Brucellosis in humans and animals. Geneva: World Health Organization in collaboration with the Food and Agriculture Organization of the United Nations and the World Organization for Animal Health. pp 1-68.

14. Al-Majali AM (2005) Seroepidemiology of caprine brucellosis in Jordan. Small Rumin Res 58: 13-18.

15. Bekele M, Mohammed H, Tefera M, Tolosa T (2011) Small ruminant brucellosis and community perception in Jijiga District, Somali Regional State, Eastern Ethiopia. Trop Anim Health Pro 43(4): 893898.

16. Tekelye B, Kasali OB (1990) Brucellosis in sheep and goats in Central Ethiopia. Bull Anim Health Prod Afr 38(1): 23-25.

17. Ferede Y, Mengesha D, Mekonen GH, melekot M (2011) Study on the seroprevalence of small ruminant brucellosis in and around Bahir Dar, North West Ethiopia. Ethiope Vet J 15(2): 35-44.

18. Hamidullah M, Khan R, Khan I (2009) Seroprevalence of brucellosis in animals in district Kohat NWFP and comparison of two serological tests. Pak Vet J 61(4): 242-243.

19. Negash E, Shihun S, Desta B (2012) Seroprevalence of small ruminant brucellosis and its public health awareness in selected sites of Dire Dawa region, Eastern Ethiopia. Journal of Vet Med and An H 4(4): 61-66.

20. Bashahun DGM, N George, Deresa B G (2015) Seroprevalence of human brucellosis community awareness and practices on its zoonotic importance in Jimma town and Chora Botor district, Ethiopia JZD 1 (1): 58-64.

21. Abdou AE (2000) Fifty years of veterinary public health activities in the Eastern Mediterranean Region. East Mediter Health J 6(4): 796807.

22. Brisibe F, Nawathe DR, Bet CJ (1996) Sheep and goat brucellosis in Borno and Yobe States of arid northeastern Nigeria. Small Rumin Res 20: 83-88.

23. (2005) CSA 2005 Estimated number of cattle, sheep and goats by region: CSA, Ethiopia.

24. Emslie FR, Nel JR (2002) An overview of the eradication of Brucella melitensis from KwaZulu-Natal. Onderstepoort J Vet Re 69(2): 123127. 
25.Hartigan P (1997) Human brucellosis: epidemiology and clinical manifestations. Ir Vet J 50: 179-180.

26. JEO Rege, W Ayalew, E Getahun (2006) Domestic animal genetic resources information system (DAGRIS) ILRI.

27. Maloney GE, Fraser WR (2004) CBRNE - Brucellosis. Omaha, Nebraska, eMedicine.

28. (2004) Pastoralist Forum Ethiopia (PFE) 2004 Background to the Ethiopian livestock industry. In Proc. 3rd National Conference on
Pastoral Development in Ethiopia: pastoralist and sustainable pastoral development, 23-24 December, Addis Ababa. PFE, Addis Ababa 7879.

29. Schelling E, Diguimbaye C, Daoud S, Nicolet J, Zinsstag J (2004) Seroprevalences of zoonotic diseases in nomads and their livestock in Chari-Baguirmi, Chad. Medicine Tropics 64(5): 474-477.

30. Young EJ (1995) An overview of human brucellosis. Clin Infect Dis 2: $283-290$

\section{Your next submission with Juniper Publishers will reach you the below assets}

- Quality Editorial service

- Swift Peer Review

- Reprints availability

- E-prints Service

- Manuscript Podcast for convenient understanding

- Global attainment for your research

- Manuscript accessibility in different formats

( Pdf, E-pub, Full Text, Audio)

- Unceasing customer service

Track the below URL for one-step submission https://juniperpublishers.com/online-submission.php 